\title{
http://bjas.journals.ekb.eg \\ Prognostic Value of Rifle Criteria for Acute Kidney Injury in the Critically ill Patients
}

\author{
Y. E. $\operatorname{Rezk}^{1}$, M.E. Ibrahim ${ }^{2}$, B. M. Aglan ${ }^{1}$ and E. A. Seif ${ }^{1}$ \\ ${ }^{1}$ Cardiothoracic surgery Dept., Faculty of Medicine, Benha Univ., Benha, Egypt \\ ${ }^{2}$ Internal medicine Dept., Faculty of Medicine, Benha Univ., Benha, Egypt
}

\begin{abstract}
Acute Kidney Injury (AKI) is a common complication of critical illness and is associated with high mortality and has a separate independent effect on the risk of death. The incidence of AKI in hospitalized patients ranged from 2$5 \%$, while the incidence of AKI in the ICU varies from 2.5 to $15 \%$, and mortality in this setting can be as high as $78 \%$ in patients who require dialysis. AKI carries helter skelter morbidity, increments those period of healing facility stay, expands clinic expenses and will be an autonomous danger element for poor Conclusion over critically sick patients. The point of this investigation might have been should examine the prognostic esteem for rifle criteria clinched alongside prediction for result for seriousness patients for intense renal failure, and its relationship for secured more seasoned frigid scoring frameworks Concerning illustration apache ii Furthermore couch scores. A test prospective, randomized clinical trial might have been conducted, 60 patients met Incorporation criteria were selected in the examine starting with those period Jun. 2019 with dec 2019. Those apache score about disappointment subgroup might have been fundamentally higher in examination should danger Furthermore harm subgroups $(\mathrm{p}=0.002)$. Those couch score of disappointment subgroup might have been essentially higher in examination with danger Also harm subgroups $(\mathrm{p}=0$. 001). In regards to Outcome, those principle Contrast the middle of the bunches might have been statistically significant, $(\mathrm{p}=0$. 002) Patients who Advance on higher rifle classes bring higher mortal sin Furthermore more drawn out frigid remain in examination with patients who didn't advancement.
\end{abstract}

E-Mail:EssamSeif@gmail.com

Keywords: AKI, Critical, Sofa, Apache, Rifle, Mortality, Complication.

\section{Introduction}

Intense kidney damage (AKI) may be An regular muddling for incredulous illness, which will be connected with secondary mortal sin and need An differentiate autonomous impact on the danger about demise. Regardless of a few progresses in medication and over our Comprehension of the pathogenesis about AKI, numerous parts in this field stay liable will controversy, disarray and absence of agreement [1].

There may be a graded relationship the middle of the measure of rise of serum creatinine Furthermore mortal sin On AKI. Creatinine elevations of $10 \%$ will $24 \%$ over benchmark brought about An relative hazard of 1.8 (1.3-2.5), patients with a Ascent of $25 \%$ with $49 \%$ required a relative hazard from claiming 3. 0 (1. 6-5.8), Also the individuals with more stupendous over half expand required An hazard about 6.9 (2. 0-24.5) [2].

The acronym rifle characterizes three evaluations for expanding seriousness for ARF (risk, injury, Also failure, respectively, R, I, and F) and two Conclusion variables (loss and end-stage kidney disease, respectively, 1 Furthermore E) [3].

Those Most exceedingly bad of Possibly creatinine criteria alternately pee yield criteria will be connected. For RIFLE, AKI ought further bolstering be unexpected (within 1-7 days). At benchmark creatinine may be elevated, a Sharp Ascent about in any event $0.5 \mathrm{mg} / \mathrm{dl}(44 \mathrm{mmol} / \mathrm{l})$ with $>4 \mathrm{mg} / \mathrm{dl}$ (354mmol/l) is addition to rifle class Failure [4].

\section{Subjects}

Also routines. An test prospective, randomized clinical trial might have been conducted, 60 patients met Incorporation criteria were selected in the ponder from those period Jun. 2019 on dec 2019.

\section{1 Consideration Criteria}

Patients admitted for typical serum creatinine level Anyway indicating brought up levels Throughout frigid remain (normal serum creatinine 1. $2 \mathrm{mg} / \mathrm{dl}$ ) Also Patients admitted with helter skelter serum creatinine levels Anyhow for known build accordance of the serum creatinine A year ago.

Prohibition Criteria: Patients with no former $\mathrm{SCr}$ worth inside a year, patients were excluded Assuming that they required an confirmation $\mathrm{SCr}$ level $>1.2$ $\mathrm{mg} / \mathrm{dL}$, Patients who were released specifically taking after those confirmation will a chance to be excluded Also Patients once incessant dialysis.

Constantly on incorporated patients were subjected of the following:. For each tolerant in the ponder group, those Emulating might have been done: full restorative history What's more clinical examination. Frigid charts were also reviewed and the information were recorded, observing the liquid status of the patients by vital venous pressure, liquid charts What's more pee output, surveying the patients by baseline, serial schedule chemistry, electrolyte, renal work tests blood vessel blood gasses What's more pee analysis, Abdominal ultrasonic What's more essential investigations on figure out those reason for renal disappointment when needed, Patients were arranged as stated by the nature about frigid confirmation should medical, surgical, unscheduled surgical (emergency unplanned operations), constantly on patients were trailed up till their discharge, Patients were ordered according the 
rifle criteria to:. Gathering 1: danger aggregation included 12 patients. Bunch 2: damage bunch incorporated 20 patients. Gathering 3: disappointment one assembly incorporated 28 patients. Requisition for couch scoring systems: [5]. The couch scoring framework is advantageous in foreseeing those clinical results for critically sick patients. Those mortality is in any event half The point when the score will be increased, in any case for introductory score, in the initial 96 hours of admission, $27 \%$ will $35 \%$ On those score remains unchanged, and short of what $27 \%$ whether the score may be diminished.

Couch score might have been computed at D1 Also D2, in light of it incorporate parameters that camwood altogether shift then afterward a couple hours, Also a serial assessment reflects An true progress in a patient's clinical condition and the impact for restorative intercessions. Those delta couch $(\triangle \mathrm{SOFA})$ might have been computed Similarly as the distinction the middle of those D2 and D1 couch score. Patients who passed on Throughout the 1 st $24 \mathrm{~h}$ were not incorporated to D2 score figuring.

Requisition about apache ii score: [6]. The purpose score will be computed from An patient's period and 12 schedule physiological measurements: $\mathrm{AaDO} 2$ or $\mathrm{PaO} 2$ (depending with respect to $\mathrm{FiO} 2$ ), temperature (rectal), intend blood vessel pressure, ph arterial, heart rate, respiratory rate, sodium (serum), Potassium (serum), Creatinine, Hematocrit, White platelet check and Glasgow unconsciousness scale. These were measured Throughout the Initially 24 hours then afterward admission, and used furthermore to data around past wellbeing status (recent surgery, history from claiming extreme organ insufficiency, immunocompromised state) and benchmark demographics for example, such that agdistis.

Apache ii score might have been computed In light of the Most exceedingly bad qualities of the main $24 \mathrm{~h}$ following ed admission, and, Eventually Tom's perusing design, it may be ascertained once after those primary $24 \mathrm{~h}$ of doctor's facility confirmation.

\section{Results}

The study enrolled 60 Patients admitted at department of critical care, Benha University. Patients were divided into three groups based on the RIFLE score on admission as follows:

- Group I: Risk group included 12 patients

- Group II: Injury group included 20 patients

- Group III: Failure group included 28 patients
Different risk scores of the whole study population show that the mean APACHE score day 1 was $19.8 \pm 5.5$, APACHE score day 2 was $22.5 \pm 6.4$, SOFA score day 1 was $8.6 \pm 2.6$ and SOFA score day 2 was $9.8 \pm 3.7$ Table (1).

Regarding GCS, the Median GCS of the study population 15 (12 - 15). Regarding CVP, the mean CVP of the study population was $12.9 \pm 7.4$. In group $\mathrm{I}$, the mean was $10.8 \pm 7.1$, Regarding MAP, the mean MAP of the study population was $68.2 \pm 10.8$. Regarding Nephropathy grade by US, The main difference between the groups was statistically significant, P value 0. 028 Table (2).

Regarding APACHE score day 1, the mean APACHE score day 1 of the study population was $19.8 \pm 5.5$. The main difference between the groups was statistically significant, $P$ value $=0.002$. Regarding APACHE score day 2, the mean APACHE score day 2 of the study population was $22.5 \pm 6.4$. The main difference between the groups was statistically significant, $\mathrm{P}$ value $=0$. 007. Regarding SOFA score day 1 , the mean SOFA score day 1 of the study population was $8.6 \pm 2.6$. The main difference between the groups was statistically significant, $\mathrm{P}$ value $<0.001$. Regarding SOFA score day 2, the mean SOFA score day 2 of the study population was $9.8 \pm 3.7$. The main difference between the groups was statistically significant, $\mathrm{P}$ value $=0.008$ Table (3).

Regarding UOP day $1(\mathrm{~mL} / 24 \mathrm{~h})$, the main difference between the groups was statistically significant, $\mathrm{P}$ value $=0$. 001. Regarding UOP day 2 $(\mathrm{mL} / 24 \mathrm{~h})$, the main difference between the groups was statistically significant, $\mathrm{P}$ value $<0.001$. Regarding GFR Cockroft day 1,. The main difference between the groups was statistically significant, $\mathrm{P}$ value $=0$. 048. Regarding GFR Cockroft day 2, the main difference between the groups was statistically significant, $\mathrm{P}$ value $=0$. 041. Regarding Hospital stay (days), the main difference between the groups was statistically significant, $\mathrm{P}$ value $<0.001$. Regarding Need for Mechanical Ventilation, the main difference between the groups was statistically significant, P value 0. 012. Regarding Outcome, the main difference between the groups was statistically significant, P value 0. 002 Table (4).

ROC curve analysis was done to pick up the best cut off value of different scores for prediction of outcome of intensive care unit patients with acute renal failure which revealed Table (5), Fig (1).

Table (1) Different risk scores of the whole study population.

\begin{tabular}{lc}
\hline Risk scores & All patients \\
\hline Count $(\%)$ & $60(100 \%)$ \\
RIFLE on admission & $12(20 \%)$ \\
Risk & 12
\end{tabular}


Table (1) Continue

\begin{tabular}{lc}
\hline Injury & $20(33.3 \%)$ \\
Failure & $28(46.7 \%)$ \\
APACHE score day 1 & \\
Mean \pm SD & $19.8 \pm 5.5$ \\
APACHE score day 2 & \\
Mean \pm SD & $22.5 \pm 6.4$ \\
SOFA score day 1 & \\
Mean \pm SD & $8.6 \pm 2.6$ \\
SOFA score day 2 & \\
Mean \pm SD & $9.8 \pm 3.7$ \\
\hline
\end{tabular}

Table (2) Comparison between the studied groups regarding the clinical data.

\begin{tabular}{|c|c|c|c|c|}
\hline Clinical data & $\begin{array}{c}\text { Group I } \\
\text { Risk }\end{array}$ & Group II Injury & Group III Failure & $\begin{array}{l}\text { P-value } \\
\text { (Sig.) }\end{array}$ \\
\hline Count & 12 & 20 & 28 & \\
\hline \multicolumn{5}{|c|}{ Type of ICU admission } \\
\hline Medical & $6(50 \%)$ & $15(75 \%)$ & $21(75 \%)$ & $0.240(\mathrm{NS})$ \\
\hline Surgical & $6(50 \%)$ & $5(25 \%)$ & $7(25 \%)$ & \\
\hline \multicolumn{5}{|l|}{ GCS } \\
\hline Median (IQR) & $15(10.25-15)$ & $14.5(10.5-15)$ & $15(13-15)$ & $0.556(\mathrm{NS})$ \\
\hline \multicolumn{5}{|l|}{ CVP (cm.H2o) } \\
\hline \multicolumn{5}{|l|}{ MAP (mmHg) } \\
\hline Mean \pm SD & $75.5 \pm 5.3$ & $68.8 \pm 13.3$ & $64.8 \pm 9.0$ & $0.012(\mathrm{~S})$ \\
\hline \multicolumn{5}{|c|}{ Nephropathy grade by US } \\
\hline Grade 0 & $4(33.3 \%)$ & $3(15 \%)$ & $3(10.7 \%)$ & $0.028(\mathrm{~S})$ \\
\hline Grade 1 & $5(41.7 \%)$ & $6(30 \%)$ & $3(10.7 \%)$ & \\
\hline Grade 2 & $2(16.7 \%)$ & $8(40 \%)$ & $9(32.2 \%)$ & \\
\hline Grade 3 & $1(8.3 \%)$ & $3(15 \%)$ & $13(46.4 \%)$ & \\
\hline
\end{tabular}

Table (3) Comparison between the studied groups regarding the risk scores.

\begin{tabular}{|c|c|c|c|c|}
\hline Clinical data & $\begin{array}{l}\text { Group I } \\
\text { Risk }\end{array}$ & Group II Injury & Group III Failure & $\begin{array}{l}\text { P-value } \\
\text { (Sig.) }\end{array}$ \\
\hline Count & 12 & 20 & 28 & \\
\hline APACHE score day 1 & & & & \\
\hline $\begin{array}{l}\text { Mean } \pm \text { SD } \\
\text { APACHE score day } 2\end{array}$ & $15.0 \pm 5.3$ & $20.7 \pm 4.6$ & $21.2 \pm 5.1$ & $0.002(\mathrm{~S})$ \\
\hline $\begin{array}{l}\text { Mean } \pm \text { SD } \\
\text { SOFA score day } 1\end{array}$ & $17.6 \pm 7.0$ & $23.0 \pm 6.2$ & $24.2 \pm 5.2$ & $0.007(\mathrm{~S})$ \\
\hline $\begin{array}{l}\text { Mean } \pm \text { SD } \\
\text { SOFA score day } 2\end{array}$ & $6.4 \pm 1.8$ & $7.9 \pm 2.8$ & $10.0 \pm 1.8$ & $<0.001(\mathrm{HS})$ \\
\hline Mean \pm SD & $7.9 \pm 2.5$ & $8.9 \pm 3.6$ & $11.3 \pm 3.6$ & $0.008(\mathrm{~S})$ \\
\hline
\end{tabular}

Table (4) Comparison between the studied groups regarding the ICU course.

\begin{tabular}{|c|c|c|c|c|}
\hline ICU course & $\begin{array}{l}\text { Group I } \\
\text { Risk } \\
\end{array}$ & $\begin{array}{l}\text { Group II } \\
\text { Injury }\end{array}$ & Group III Failure & $\begin{array}{l}\text { P-value } \\
\text { (Sig.) }\end{array}$ \\
\hline Count & 12 & 20 & 28 & \\
\hline $\begin{array}{l}\text { UOP day } 1(\mathrm{~mL} / 24 \mathrm{~h}) \\
\text { Median (IQR) } \\
\text { UOP day } 2(\mathrm{~mL} / 24 \mathrm{~h})\end{array}$ & $1400(850-2000)$ & $800(625-1000)$ & $600(500-800)$ & $0.001(\mathrm{~S})$ \\
\hline $\begin{array}{l}\text { Median (IQR) } \\
\text { GFR Cockroft day } 1\end{array}$ & $1500(1225-2225)$ & $800(600-1450)$ & $400(225-638)$ & $<0.001(\mathrm{HS})$ \\
\hline $\begin{array}{l}\text { Mean } \pm \text { SD } \\
\text { GFR Cockroft day } 2\end{array}$ & $31.3 \pm 20.4$ & $29.9 \pm 18.9$ & $26.3 \pm 13.6$ & $0.048(\mathrm{~S})$ \\
\hline $\begin{array}{l}\text { Mean } \pm \text { SD } \\
\text { Table (4) Contine }\end{array}$ & $28.2 \pm 16.2$ & $20.0 \pm 11.8$ & $16.8 \pm 11.6$ & $0.041(\mathrm{~S})$ \\
\hline
\end{tabular}




\begin{tabular}{lcccc}
\hline GFR MDRD day 1 & & & & \\
Mean \pm SD & $43.3 \pm 39.7$ & $23.1 \pm 20.4$ & $23.9 \pm 16.1$ & $0.044(\mathrm{~S})$ \\
GFR MDRD day 2 & $20.7 \pm 15.5$ & $14.6 \pm 11.3$ & $14.5 \pm 8.5$ & $0.045(\mathrm{~S})$ \\
$\begin{array}{l}\text { Mean } \pm \text { SD } \\
\text { Hospital stay (days) }\end{array}$ & $9.4 \pm 13.0$ & $23.3 \pm 9.7$ & $40.5 \pm 5.9$ & $<0.001(\mathrm{HS})$ \\
$\begin{array}{l}\text { Mean } \pm \text { SD } \\
\text { Need for MV }\end{array}$ & $2(16.7 \%)$ & $7(35 \%)$ & $18(64.3 \%)$ & $0.012(\mathrm{~S})$ \\
& & & & $0.002(\mathrm{~S})$ \\
Outcome & $7(58.3 \%)$ & $7(35 \%)$ & $5(17.9 \%)$ & \\
$\begin{array}{l}\text { Recovery } \\
\text { Injury-failure }\end{array}$ & $3(25 \%)$ & $9(45 \%)$ & $7(25 \%)$ & \\
Death & $2(16.7 \%)$ & $4(20 \%)$ & $16(57.1 \%)$ & \\
\hline
\end{tabular}

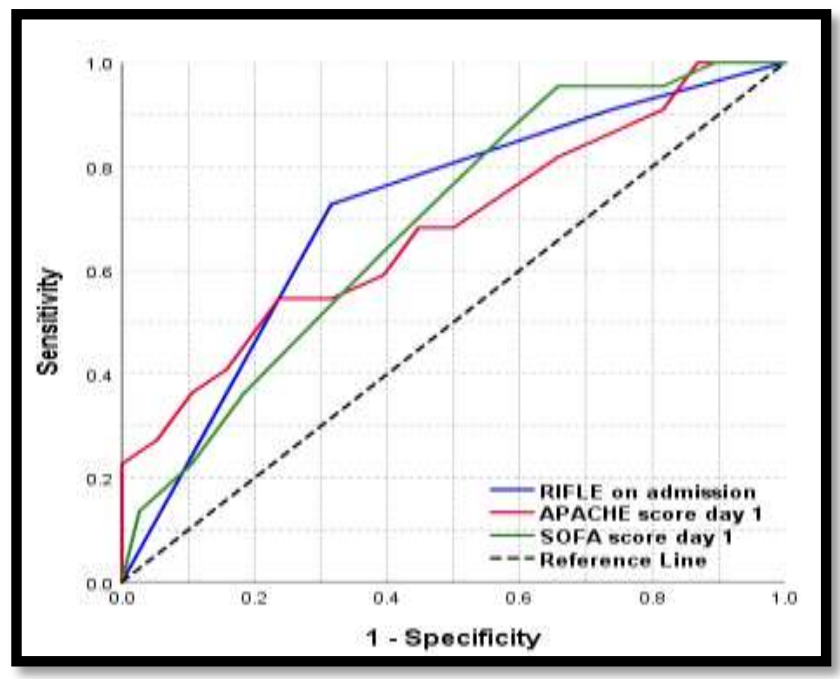

Fig (2) ROC curve analysis for risk scores in prediction of death

Table (5) The cut-off value of different risk scores; ROC curve analysis.

\begin{tabular}{|c|c|c|c|c|c|c|c|}
\hline Cut-off value & $\begin{array}{c}\text { Sensetivity } \\
\% \\
(95 \% \text { CI })\end{array}$ & $\begin{array}{c}\text { Specificity } \\
\% \\
\text { (95\% CI) }\end{array}$ & $\begin{array}{c}\text { PPV \% } \\
(95 \% \text { CI) }\end{array}$ & $\begin{array}{c}\text { NPV \% } \\
(95 \% \text { CI) }\end{array}$ & $\begin{array}{c}\text { Accuracy } \\
\% \\
(95 \% \text { CI })\end{array}$ & $\begin{array}{l}\text { AUROC } \\
(95 \% \text { CI })\end{array}$ & $\begin{array}{c}\text { P-value } \\
\text { (Sig.) }\end{array}$ \\
\hline RIFLE $\geq 3$ & $\begin{array}{c}72.7 \% \\
(49.8- \\
89.3)\end{array}$ & $\begin{array}{l}68.4 \% \\
(51.4- \\
82.5)\end{array}$ & $\begin{array}{c}57.1 \% \\
(37.2- \\
75.5)\end{array}$ & $\begin{array}{c}81.3 \% \\
(63.6- \\
92.8)\end{array}$ & $\begin{array}{c}70 \% \\
(56.8- \\
81.2)\end{array}$ & $\begin{array}{c}0.711 \\
(0.561-0.815)\end{array}$ & $\begin{array}{l}0.001 \\
(\mathrm{~S})\end{array}$ \\
\hline APACHE $\geq 20$ & $\begin{array}{c}63.6 \% \\
(40.7- \\
82.8)\end{array}$ & $\begin{array}{c}57.9 \% \\
(40.8- \\
73.7)\end{array}$ & $\begin{array}{c}46.7 \% \\
(28.3- \\
65.7)\end{array}$ & $\begin{array}{c}73.3 \% \\
(54.1- \\
87.7)\end{array}$ & $\begin{array}{c}60 \% \\
(46.5- \\
72.4)\end{array}$ & $\begin{array}{c}0.682 \\
(0.508-0.802)\end{array}$ & $\begin{array}{l}0.014 \\
(\mathrm{~S})\end{array}$ \\
\hline SOFA $\geq 9$ & $\begin{array}{c}63.6 \% \\
(40.7- \\
82.8) \\
\end{array}$ & $\begin{array}{c}60.5 \% \\
(43.4- \\
76.0) \\
\end{array}$ & $\begin{array}{c}48.3 \% \\
(29.5- \\
67.5) \\
\end{array}$ & $\begin{array}{c}74.2 \% \\
(55.4- \\
88.1) \\
\end{array}$ & $\begin{array}{c}61.7 \% \\
(48.2- \\
73.9) \\
\end{array}$ & $\begin{array}{c}0.688 \\
(0.529-0.800)\end{array}$ & $\begin{array}{l}0.006 \\
(\mathrm{~S})\end{array}$ \\
\hline
\end{tabular}

\section{Discussion}

Intense kidney harm is usually diagnosed in therapeutic ICUs crosswise over the universe Also may be portrayed by horribleness identified with its systemic sequelae Also its extra-renal organ framework impacts [7].

Past epidemiologic investigations describing the occurrence and results of AKI over critically sick patients bring been restricted because of the contrasts utilized within characterizing and classifying AKI [8].

RIFLE, an universal agreement arrangement to AKI, characterizes three evaluations about seriousness - danger (class R), harm (class I) What's more disappointment (class F) - Anyhow need not yet been assessed over a clinical arrangement [9].

What added up to 60 patients were assessed On our consider. Patients were isolated under three bunches dependent upon the rifle score once confirmation.

The Contrast the middle of those gatherings might have been statistically non-significant ( $\mathrm{p}$ esteem 0 . 
490) which might have been tantamount to Lopes et al. , who examination the middle of the rifle and the intense kidney harm organize characterizations in seriousness patients who news person sex from claiming as much patients were (59.2\%) male Also (40. $8 \%$ ) female Also statistically non-significant Contrast the middle of the Assemblies for $\mathrm{p}$ esteem 0 . 252 [10].

In the present study, we found that those kind about frigid confirmation for patients might have been $(70 \%)$ restorative Also (30\%) surgical.

Those Contrast between those Assemblies might have been statistically non-significant ( $\mathrm{p}$ esteem 0 . 240) which might have been unique towho examine rifle criteria for intense kidney harm Furthermore frequency from claiming clinic mortal sin in critically sick patients Furthermore discovered that patients admitted to medicinal cause might have been $44.2 \%$ Also for surgical cause might have been $55.8 \%$ with statistically huge distinction between those examined aggregations with p quality $<0.001$ [11].

In the present study, we found that those mean of frigid remain might have been $28.6 \pm 15$. 1 times.

The Contrast between the gatherings might have been statistically noteworthy ( $\mathrm{p}$ worth $<0.001$ ) which might have been tantamount to On which intense kidney Injury-Epidemiologic Prospective examination examine performed done 97 focuses on patients Throughout the main week about frigid confirmation Also discovered statistically huge Contrast the middle of the concentrated on bunches for $\mathrm{p}$ quality $<0.001$ in regards period of sit tight frigid (days) [8].

In the present study, we discovered that those GCS for patients might have been 15 average 12-15.

The Contrast between the Assemblies might have been statistically non-significant (p quality 0. 556) which might have been unique with done which 263 patients with intense kidney harm Previously, seriousness assessed to incidence, danger figures What's more mortality What's more found the imply GCS 9. 01with sd \pm 4 . 15 What's more statistically noteworthy Contrast the middle of the examined aggregations for $\mathrm{p}$ worth $<0.001[12]$.

In the present study, we found that assessed GFR might have been statistically critical in the $1 \mathrm{st}$ Furthermore second day (p quality significant) which might have been tantamount to On which intense kidney Injury-Epidemiologic Prospective examination study performed done 97 focuses on patients Throughout the Initially week of frigid confirmation Furthermore discovered statistically noteworthy Contrast between the mulled over gatherings for p quality < 0.001 in regards GFR [8].

In the current study, we found that apache score might have been statistically noteworthy in the $1 \mathrm{st}$ Furthermore second day (p worth 0.002 and 0.007 irrespectively) which might have been tantamount to who research predictive limit for in-hospital mortal sin about seriousness score frameworks ahead critically sick patients with intense kidney harm and discovered that imply apache score 1 st day might have been 16 and the Contrast the middle of those contemplated bunches statistically non-significant for p worth 0.099 same time apache score done entirety healing center sit tight might have been statistically critical for p quality $<0.001$ [13].

In this study, we found that couch score might have been statistically huge in the main and second day (p quality <0. 001 Also 0.008 irrespectively) which might have been tantamount to who assessment about intense kidney harm (AKI) with RIFLE, and KDIGO to critically sick trauma patients Furthermore found statistically huge distinction the middle of the mulled over bunches for $\mathrm{p}$ worth $<0$. 001 in regards couch score [14].

To our ponder the best cut off quality of different scores to prediction from claiming result for seriousness patients for intense renal disappointment which uncovered rifle $\geq 3$ with affectability $72.7 \%$, specificity $68.4 \%$, territory under the bend 0.711 and correctness $70 \%$ (P-value 0. 001), apache $\geq 20$ with affectability $63.6 \%$ specificity $57.9 \%$, territory under those bend 0.682 and exactness $60 \%$ (P-value 0 . 014) Furthermore couch $\geq 9$ for affectability 63 . $6 \%$, specificity $60.5 \%$, zone under those bend 0.688 and exactness $61.7 \%$ (P-value 0. 006).

In understanding with who explore predictive limit from claiming in-hospital mortal sin of seriousness score frameworks with respect to critically sick patients for intense kidney damage Also discovered that couch score need affectability 90. $76 \%$ specificity $71.43 \%$ done prediction about result from claiming seriousness patients for intense renal disappointment Furthermore apache score need affectability $90.76 \%$ specificity $77.14 \%$ [13].

\section{Determination}

Patients who advancement should higher rifle classes need higher mortal sin Also more frigid sit tight in examination on patients who didn't Advance.

\section{References}

[1] J. Wang, MJ. Dunn, Platlet-activating factor mediates endotoxin-induced acute renal insufficiency in rats. Diagnosis and treatment of acute tubular necrosis. Ann Intern Med, Vol.137, PP.744-52, 2002.

[2] C. Thongprayoon, W. Cheungpasitporn, N. Srivali, P. Ungprasert, W. Kittanamongkolchai, \& K. J. J. O. N. Kashani, The impact of fluid balance on diagnosis, staging and prediction of mortality in critically ill patients with acute kidney injury, Vol.29, PP.221-227, 2016.

[3] S. M. Sutherland, J. J. Byrnes, M. Kothari, C. A. Longhurst, S. Dutta, P. Garcia, et al., AKI in hospitalized children: comparing the pRIFLE, AKIN, and KDIGO definitions, Vol.10, PP.554$561,2015$. 
[4] M. Ostermann, \& M. J. C. C. Joannidis, Acute kidney injury 2016: diagnosis and diagnostic workup, Vol.20, PP.299-306, 2016.

[5] J.L. Vincent, R. Moreno, J. Takala, S. Willatts, A. De.Mendonca, H. Bruining, The SOFA (sepsis related organ failure assessment) score to describe organ dysfunction/failure. Intensive Care Med, Vol.22, PP.707-10, 1996.

[6] A. Knaus,E.A.Draper,D.P.wagner,J.E. Zimmerman, APACHE II: a severity of disease classification system. Crit Care Med;vol. 13, PP.818-29, 1985.

[7] G. Seller-perez, S. Más-font, C. Perez-calvo, P. Villa-DíAZ, M. Celaya-lópez, \& M. HerreraGutierrez, Acute kidney injury: Renal disease in the ICU. Medicina Intensiva (English Edition) ;vol. 40, PP.374-382, 2016.

[8] E. A. Hoste,S. M. Bagshaw,R. Bellomo,C. M. Cely,R. Colman, D.N.Cruz, Epidemiology of acute kidney injury in critically ill patients: the multinational AKI-EPI study. Intensive Care Med, Vol.41, PP.1411-23, 2015.

[9] A. Bihorac, S. Yavas, S. Subbiah, C. E. Hobson, J. D. Schold, A. Gabrielli, Long-term risk of mortality and acute kidney injury during hospitalization after major surgery. Annals of surgery, Vol.249, PP.851-858, 2009.

[10] J.A.Lopes,P. Fernandes,S.Jorge,S. Goncalves, A. Alvarez, Z. C. E Silva, Acute kidney injury in intensive care unit patients: a comparison between the RIFLE and the Acute Kidney Injury Network classifications. Critical Care;vol.12, pp.110-121, 2008.

[11] EA. Hoste, G. Clermont, A. Kersten, R. Venkataraman, D.C. Angus, De.D. Bacquer, RIFLE criteria for acute kidney injury are associated with hospital mortality in critically ill patients: a cohort analysis. Crit Care;vol. 10, pp.73-82, 2006.

[12] H. R. Samimagham, S. Kheirkhah, A. Haghighi, \& Z. Najmi, Acute kidney injury in intensive care unit: incidence, risk factors and mortality rate. Saudi journal of kidney diseases and transplantation: an official publication of the Saudi Center for Organ Transplantation, Saudi Arabia;vol. 22, PP.464-470, 2011.

[13] Y.Gong, F. Ding, F. Zhang, \& Y. GU, Investigate predictive capacity of in-hospital mortality of four severity score systems on critically ill patients with acute kidney injury. Journal of Investigative Medicine, Vol.32 ,pp.201-221,2019.

[14] F. Ülger, M. P. Kucuk, A. Kucuk, N. İlkaya, N. Murat, B. BILGIC, Evaluation of acute kidney injury (AKI) with RIFLE, AKIN, CK, and KDIGO in critically ill trauma patients. European Journal of Trauma and Emergency Surgery; vol. 44, PP.597-605, 2018. 